\title{
IMPLEMENTASI KURIKULUM 2013 PAI DALAM PEMBENTUKAN KARAKTER PESERTA DIDIK SDN PELITA KARYA DAN SDN CINTAMARGA \\ Sukini
}

Universitas Islam Nusantara, Indonesia

E-mail: Sukini1809@gmail.com

\section{Diterima:}

21 Juli 2021

Direvisi:

11 Agustus 2021

Disetujui:

15 Agustus 2021

\section{Abstrak}

Fenomena dekadensi moral terjadi akibat tidak terkendalikannya kemajuan dari teknologi yang berkembang begitu pesat, selain itu juga pengaruh budaya luar mewarnai terjadinya dekadensi moral. Pengaruh dekadensi moral ini cenderung kapada hal-hal yang negatif. Di sinilah impementasi kurikulum 2013 PAI perlu didesain sesuai dengan kebutuhan. Implementasi kurikulum 2013 PAI menjadi pedoman dalam pembelajaran untuk pembentukan karakter peserta didik. karena kurikulum sifatnya dinamis sesuai dengan kebutuhan, untuk itu perlu adanya kurikulum yang orientasinya pada penanaman sikap baik spiritual maupun sosialnya, dengan kata lain harus dimunculkan pendidikan karakter. Implementasi kurikulum 2013 di dalamnya ada pendidikan karakter. Implementasi kurikulum 2013 Pendidikan Agama Islam dalam pembelajaran. Metode penelitian yang digunakan adalah metode deskriptif analitis kualitatif dengan pendekatan teknik survey. Penelitian ini menggunakan teknik analisis data kualitatif model interaktif yang terdiri dari tiga alur kegiatan yang terjadi secara bersamaan yaitu reduksi data. Dari hasil pengamatan dan pembahasan disimpulkan bahawa : (1) Implementasi kurikulum 2013 Pendidikan Agama Islam di kelas VI SD Negeri Pelita Karya Jalancagak Subang dapat dilaksanakan dengan sangat baik, (2) Karakter peserta didik kelas VI SD Negeri Pelita Karya Jalancagak Subang, menunjukkan karakteristik yang baik sampai dengan sangat baik sesuai dengan indikator karakter yang ditetapkan, (3) setelah diterapkan kurikulum 2013, perubahan perilaku peserta didik menunjukkan perubahan yang signifikan, (4) Fakor faktor penghambat di SD Negeri Pelita Karya dalam implementasi kurikulum 2013 adalah ketersediaan waktu dan sarana pembelajaran yang sangat terbatas.

Kata kunci: Implementasi, Kurikulum, Karakter Peserta Didik

Abstract
The phenomenon of moral decadence occurs due to the
uncontrolled progress of technology that is developing so
rapidly, in addition to the influence of outside cultures coloring
the occurrence of moral decadence. The influence of this moral
decadence tends to be negative. This is where the
implementation of pai 2013 curriculum needs to be designed
according to the needs. The implementation of pai 2013
curriculum becomes a guideline in learning for the formation of
student character. because the curriculum is dynamic according


to the needs, therefore there needs to be a curriculum whose orientation on the cultivation of attitudes both spiritual and social, in other words should be raised character education. The implementation of the 2013 curriculum in it has character education. Implementation of the 2013 Islamic Religious Education curriculum in learning. The research method used is qualitative analytical descriptive method with survey technique approach. This study uses qualitative data analysis techniques of interactive models consisting of three flow of activities that occur simultaneously, namely data reduction. From the observations and discussions concluded that: (1) Implementation of the curriculum 2013 Islamic Religious Education in grade VI SD Negeri Pelita Karya and SD Negeri Cintamarga Jalancagak Subang can be implemented very well, (2) The character of grade VI students of SD Negeri Pelita Karya and SD Negeri Cintamarga Jalancagak Subang, shows good characteristics up to very well in accordance with the character indicators set, (3) after the 2013 curriculum was implemented, changes in student behavior showed significant changes in, (4) Fakor inhibitory factors at SD Negeri Pelita Karya and SD Negeri Cintamarga in the implementation of the 2013 curriculum is the availability of time and learning facilities that are very limited s.

Keywords: implementation, Curriculum, Student Character

\section{Pendahuluan}

Pendidikan pada dasarnya adalah upaya untuk membantu peserta didik agar dapat mengembangkan seluruh potensi yang dimilikinya menjadi manusia yang mempunyai kecakapan utuh, sehingga dengan kecakapanya ia dapat dengan mudah menjalani dan menghadapi segala persoalan kehidupan (Mubarrok, 2019). Pemerintah melalui Kementrian Pendidikan dan Kebudayaan, telah melakukan rangkaian aktivitas pembaharuan guna meningkatkan mutu, martabat bangsa, dan Negara melalui sumber daya pendidikan, unsur-unsur sumber daya pendidikan ini yang tidak kalah pentingnya yaitu kurikulum yang merupakan salah satu unsur yang dapat mengkontribusikan secara signifikan untuk mewujudkan proses berkembangnya kualitas bangsa yang kuat dan bermartabat. Bangsa yang bermartabat adalah bangsa yang menjungjung tinggi nilai-nilai kemanusiaan yaitu salah satunya nilai sikap karakter. Pendidikan adalah daya upaya untuk memajukan bertumbuhnya budi pekerti (kekuatan batin, karakter), pikiran (intelek) dan tubuh anak dalam rangka kesempurnaan hidup dan keselarasan dunianya (Susanto \& Retnaningsih, 2018).

Tujuan pendidikan menurut UU No. 20 Tahun 2003 tentang Sistem Pendidikan Nasional (SISDIKNAS) pasal 3, tujuan pendidikan nasional adalah mengembangkan potensi peserta didik agar menjadi manusia yang beriman dan bertaqwa kepada Tuhan Yang Maha Esa, berakhlak mulia, sehat, berilmu, cakap, kreatif, mandiri, dan menjadi warga Negara yang demokratis serta bertanggung jawab (Wahono, 2018). Rumusan tersebut terungkap tiga segi yang sangat penting. Pertama, lima dari tujuh karakter manusia yang hendak dicapai melalui pendidikan menyangkut aspek afektif, yaitu: ketaqwaan, akhlak mulia, semangat kebangsaan dan cinta tanah air. Kedua berkenaan dengan pembangunan manusia Indonesia dari aspek intelektual kognitifnya yaitu kecerdasan. Ketiga berkenaan dengan aspek psikomotornya, yaitu membangun manusia 


\section{Volume 1, Nomor 8, Agustus 2021 p-ISSN 2774-7018; e-ISSN 2774-700X}

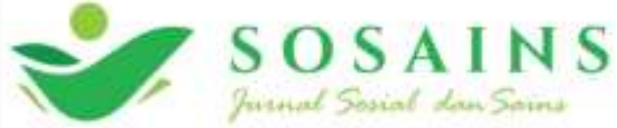

terampil dan kreatif. Ketiga bulatan kecerdasan di atas adalah buah daripada pendidikan, yaitu bukan hanya mencerdaskan anak bangsa secara intelektualnya saja, melainkan harus dengan cerdas emosional dan spritualnya.

Tujuan dari pendidikan nasional ini terkadang tidak berjalan sesuai dengan yang diharapkan. Dunia pendidikan di Indonesia saat ini ditantang untuk menjawab berbagai perubahan global yang terjadi begitu cepat (Noor, 2019). Berkembangnya teknologi, seni, budaya, dan ilmu pengetahuan terutama akselerasi transformasi dan teknologi informasi yang begitu dahsyat merubah kehidupan peradaban manusia (Suradi, 2018). Perubahan ini berdampak pula kepada bidang pendidikan yang merupakan akar dari peradaban manusia. Dekadensi moral sekarang ini semakin mengkhawatirkan karena banyak sekali yang menimpa kepada peserta didik.

Kurikulum adalah semua pembelajaran yang dirancang dan dilaksanakan secara individu ataupun secara kelompok, baik di sekolah maupun di luar sekolah (Nurdyansyah \& Fahyuni, 2016). Kurikulum 2013 adalah sebuah kurikulum yang dikembangkan untuk meningkatkan dan menyeimbangkan kemampuan soft skills dan hard skills yang berupa sikap, keterampilan, dan pengetahuan (Ayda, 2020). Implementasi kurikulum 2013 di sekolah dasar ini untuk menjawab tangtangan abad 21, dengan melibatkan beberapa komponen untuk mewujudkan tujuan pendidikan nasional dan Pendidikan Agama Islam, yaitu membentuk manusia yang memiliki ketakwaan kepada Tuhan Yang Maha Esa dan berakhlakul karimah (Djaelani, 2013).

Fenomena dekadensi moral terjadi akibat tidak terkendalikannya kemajuan dari teknologi yang berkembang begitu pesat, selain itu juga pengaruh budaya luar mewarnai terjadinya dekadensi moral (Hisyam \& Pamungkas, 2016). Pengaruh dekadensi moral ini cenderung kapada hal-hal yang negatif. Di sinilah impementasi kurikulum 2013 PAI perlu didesain sesuai dengan kebutuhan. Implementasi kurikulum 2013 PAI menjadi pedoman dalam pembelajaran untuk pembentukan karakter peserta didik di kelas VI SDN Pelita Karya dan SDN Cintamarga Jalancagak Subang.

Penelitian ini bertujuan untuk memperoleh gambaran terkait implementasi kurikulum 2013 Pendidikan Agama Isalam dalam pembentukan karakter peserta didik kelas VI di SD Negeri Pelita Karya Jalancagak Subang, mengetahui Implementasi Kurukulum 2013 Pendidikan Agama Islam di kelas VI SD Negeri Pelita Karya Jalancagak Subang, mengetahui Karakter peserta didik kelas VI SD Negeri Pelita Karya Jalancagak Subang, mengetahui implementasi Kurikulum 2013 Pendidikan Agama Islam dalam pembentukan karakter peserta didik kelas VI SD Negeri Pelita Karya Jalancagak Subang, mengetahui faktor-faktor apa saja yang menjadi pendukung dalam implementasi kurikulum PAI dalam pembentukan karakter peserta didik di SD Negeri Pelita Karya Jalancagak Subang, mengetahui faktor faktor apa saja yang menjadi penghambat dalam implementasi kurikulum PAI dalam pembentukan karakter peserta didik di SD Negeri Pelita Karya Jalancagak Subang.

Manfaat penelitian ini adalah dapat membantu para guru mengenai kesulitankesulitan dalam mengimplementasikan kurikulum 2013 PAI dalam pembentukan karakter peserta didik SD Negeri Pelita Karya Jalancagak Subang. Selain itu penelitian ini dapat dijadikan sebagai masukan bagi para peneliti untuk melakukan penelitian secara komperhensif, dan sebagai masukan bagi pengambil kebijakan dalam menentukan keputusan dan srategi implementasi kurikulum 2013 pada Pendidikan Agama Islam di SDN Pelita Karya dan SDN Cintamarga Kecamatan Jalancagak Subang.

\section{Metode Penelitian}

Penelitian ini dilaksanakan di SD Negeri Pelita Karya Jalancagak Subang. Penentuan tempat penelitian ini didasarkan pada pertimbangan efektivitas dan efisiensi 
penelitian. Kedua sekolah dasar yang dijadikan tempat penelitian sudah lama berdirinya dan menjadi tujuan bagi sebagai besar masyarakat sekitar Desa Tambakmekar Jalancagak Subang. Selain itu peneliti sudah banyak mengenal situasi dan kondisi kedua sekolah dasar tersebut, baik dari segi lokasi, perilaku masyarakat sekitarnya, serta pengelolaan sekolah, sehingga akan mempermudah pelaksanaan penelitian dan memperoleh data yang diperlukan, yang pada gilirannya penelitian yang dilakukan akan memiliki validitas dan reliabilitas yang tinggi. Penelitian ini menggunakan pendekatan kualitatif yaitu penelitian yang bertujuan untuk menggambarkan keadaan atau suatu fenomena yang terjadi.

\section{Hasil dan Pembahasan}

Hasil pengamatan terhadap dokumentasi yang lainnya di SD Negeri Pelita Karya adalah catatan atau data mengenai karakter yang diamati oleh wali kelas VI. Diperoleh gambaran karakter skor rata-rata peserta didik kelas VI SD Negeri Pelita Karya dengan penerapan kurikulum 2013 pada pelajaran PAI. Menurut wali kelas di kedua sekolah menunjukkan bahwa, untuk peserta didik kelas VI SD Negeri Pelita Karya dikategorikan sangat baik. Sedang untuk peserta didik kelas VI SD Negeri Cintamarga dengan kategori sangat baik.

Dokumentasi merupakan teknik penilaian yang dilakukan secara berkesinambungan dengan menggunakan data, baik secara langsung maupun tidak langsung dengan menggunakan instrumen yang berisi sejumlah indikator yang sesuai dengan implementasi kurikulum 2013 PAI (Andriani, 2017). Penilaian dokumentasi langsung dilaksanakan oleh peneliti terhadap arsip yang ada di kedua sekolah tanpa perantara orang lain.

Perolehan data melalui observasi, kegiatan wawancara maupun hasil analisis dokumentasi menunjukkan hasil yang saling berkaitan dan saling mendukung (Yusuf \& Asrifan, 2020). Hal ini menunjukkan bahwa implementasi kurikulum 2013 pada pelajaran Pendidikan Agama Islam di kelas VI SD Negeri Pelita Karya Jalancagak Kabupaten Subang dapat dikatakan berhasil dan sesuai dengan harapan. Keberadaan kepala sekolah, guru dan komite sekolah di kedua sekolah menunjukkan kinerja secara sinergi dan terintegrasi, sehingga implementasi kurikulum dapat dilaksanakan dengan sangat baik (Yusmina \& Murniati, 2014). Begitu juga sarana dan prasarana pendukung untuk kelancaran pelaksanaan program sudah relatif tersedia sehingga kendala yang ada dapat diminimalisir.

Dari sekian banyak tantangan yang dihadapi oleh kepala sekolah, mengelola perubahan dalam penggunaan kurikulum pembelajaran adalah salah satu yang paling sulit (Mataputun, 2018). Salah satu alasan kepemimpinan menjadi begitu penting adalah bahwa dunia pendidikan telah semakin penuh persaingan, dan perubahan dalam desain kurikulum, struktur kurikulum, maupun kepemimpinan sangat diperlukan untuk bertahan hidup dalam lingkungan pendidikan dengan kurikulum baru. Sekolah harus diorganisasi kembali untuk menghilangkan kegiatan-kegiatan operasi yang tidak diperlukan dan tidak diinginkan oleh kurikulum, menuju perubahan dalam pengelolaan pembelajaran (Indrawan, 2015). Di saat perubahan kurikulum dilaksanakan, tantangan, hambatan dan peluang yang dihasilkan oleh hubungan baru tidak terelakkan.

Kepala sekolah sebagai pemimpin harus memiliki kredibilitas dan reputasi yang hebat, agar ia mampu memberikan inspirasi dan motivasi kepada setiap orang. Pemimpin harus memotivasi dan menginspirasi setiap orang dalam setiap detik kehidupan mereka, untuk bersemangat dan bangkit bersama dengan perubahan baru. Pemimpin harus membuat setiap orang menyadari bahwa perubahan itu penting, untuk mengubah hal-hal yang tertinggal zaman dengan hal-hal baru yang sesuai peradaban. 
Kepala sekolah harus memiliki keterampilan untuk dapat mengenali perubahanperubahan penting, serta mampu mengambil tempat di dalam hati setiap orang, agar semua orang dalam organisasi bisa saling menyatu dan saling berempati, untuk membawa perubahan itu ke arah yang lebih memberi manfaat positif buat organisasi dan buat setiap manusianya. Kepala sekolah juga harus bisa membangkitkan semangat dan gairah perubahan dari setiap orang di dalam organisasi untuk menyesuaikan diri dengan lebih cepat, serta berjuang keras dan bekerja keras untuk mendapatkan hasil perubahan yang lebih baik dari rencana yang ada (Huda, 2014). Kepala sekolah harus menyadarkan setiap orang, agar selalu menggunakan cara-cara profesionalisme dalam merespon setiap perubahan. Untuk itu, pemimpin harus duduk bersama dengan semua kekuatan sumber daya manusianya, untuk berbicara tentang perubahan-perubahan itu dengan cara-cara penuh inspirasi dan profesional.

Berdasarkan hasil pengamatan dan wawancara secara langsung, bahwa kepala sekolah sebagai pemimpin dapat dikatakan cerdas dalam menggunakan tema perubahan di sekolah masing masing, sebagai sarana untuk meningkatkan keuntungan kompetitif di bidang peningkatan kinerja sekolah. Kepala sekolah bisa menggambarkan perubahan itu secara nyata di pikiran setiap orang (stakeholders), dan memberikan cermin perubahan untuk dapat dilihat setiap orang tentang wujud asli dari perubahan tersebut. Kepala sekolah mampu memberi inspirasi kepada setiap orang, untuk menghadapi perubahan dalam pekerjaan, untuk menghadapi perubahan dalam keluarga, untuk menghadapi perubahan dalam hidup. Dan dalam semua aspek yang bertujuan untuk meningkatkan gairah dan kepercayaan diri organisasi, untuk memenangkan persaingan dalam kompetisi yang ketat.

Kepala sekolah menunjukkan kemampuan yang prima di dalam mengajak dan menggandeng setiap hati dan setiap pikiran, untuk berpikir dan bertindak dalam semangat meningkatkan semua potensi sekolah, serta mampu menangani semua potensi hebat secara lebih baik, dengan cara mengubah hal-hal yang menghambat gerak sukses aktiitas sekolah. Kepala sekolah juga menunjukkan kecerdasannya dalam membimbing guru guru untuk berhenti berwacana secara berkepanjangan, dan mengajak setiap orang (stakeholders) untuk melakukan tindakan-tindakan yang membantu kemajuan sekolah. Tindakan yang terfokus pada upaya meningkatkan kinerja, dalam kemampuan manajemen menghadapi perubahan yang tak pasti.

Kepala sekolah selalu menggunakan pola atau model berpikir yang sederhana dan jelas, agar setiap orang di dalam organisasi (stakeholders) tidak terjebak dalam cara berpikir yang merumitkan, sehingga makna perubahan di bidang implementasi kurikulum itu tidak menjadi kabur. Pola berpikir yang lebih sederhana akan mendekatkan semua solusi terbaik melalui logika dan akal sehat, yang dapat diukur kebenarannya. Oleh karena itu, berpikir sederhana akan menuntun kepala sekolah dan seluruh stakeholders dalam jalur yang tidak rumit untuk menemukan segala macam solusi terbaik, dimana semua solusi itu masih bisa diukur kebenarannya dengan pikiran jernih yang berlogika cerdas; semua solusi terbaik pada dasarnya telah ada, hanya saja diperlukan keandalan kepemimpinan kepala sekolah yang solid dan kuat, untuk menjadi lebih sederhana, jernih, dan sabar dalam menyusuri jalur sederhana menuju puncak penghasil solusi andal buat sebuah perubahan yang hebat dan bermanfaat. Kepala sekolah bersifat dan bersikap yang solid dan kuat, sehingga mampu menjadi bintang yang hebat, dalam setiap gerak dan langkah ke perubahan yang lebih baik. Dapat dikatakan bahwa kepala sekolah di SD Negei Pelita Karya adalah sang pemimpin pembawa perubahan dalam implementasi kurikulum 2013 di sekolah masing masing, yang membahagiakan hati setiap orang dalam dekapan rasa damai dan rasa nyaman. 
Beberapa langkah konstruktif yang dilakukan oleh kepala sekolah di kedua sekolah dapat dideskripsikan sebegai berikut :

1. Mengidentifikasi Kebutuhan untuk Perubahan, Perubahan kurikulum di sekolah hanya dapat dimulai dengan menanggapi ketidakmampuan atau ketidak-efisienan dalam memenuhi kebutuhan pendidikan dan perkembangan peserta didik. Jika pengelolaan sekolah tidak memenuhi kebutuhan operasional, maka orang-orang yang bertanggung jawab untuk pemenuhan tersebut perlu dibuat sadar akan fakta itu. Perubahan kurikulum di sekolah yang tidak dibutuhkan mungkin adalah salah satu dari beberapa hal yang mengecewakan stakeholders dalam menyepakati lingkungan pendidikan. Jika individu yang dipengaruhi oleh perubahan kurikulum tersebut tidak menyadari tentang alasan mengapa perubahan diperlukan, mudah untuk mengasumsikan perubahan adalah sembrono. Perlunya perubahan kurikulum di sekolah harus nyata, dan itu harus diketahui oleh mereka yang akan terkena dampak. Salah satu cara terbaik yang dilakukan kepala sekolah untuk mengidentifikasi kebutuhan untuk perubahan kurikulum di sekolah dan sekaligus mendapatkan persetujuan adalah dimulai dengan memberitahukan informasi tentang perubahan kurikulum untuk meminta bantuan dari orang-orang yang akan terkena dampak perubahan. Dalam rangka meminta bantuan ini, salah satu yang dibutuhkan adalah pertama- tama menentukan siapa yang akan terkena dampak (stakeholders).

2. Mengidentifikasi Pihak-pihak yang Terkena Dampak, Kepala sekolah melakukan langkah identifikasi terhadap orang-orang yang akan terkena dampak oleh perubahan kurikulum mungkin bagian yang paling mudah dari proses manajemen perubahan. Kepala sekolah memulai dengan alasan mengapa perubahan kurikulum diperlukan. Seringkali hal ini tampak tidak jelas Alasan sebenarnya untuk kinerja yang tidak bagus dalam institusi pendidikan mungkin disebabkan oleh inefisiensi dalam pengelolaan pendidikan yang sama sekali berbeda dari kondisi pertama yang bergantung padanya. Kepedulian utama dari kepala sekolah adalah untuk memastikan akar masalah telah ditemukan, dan tidak bereaksi terhadap apa yang terlihat di permukaan. Setelah kepala sekolah merasa yakin bahwa semua orang (stakeholders) telah teridentifikasi, selanjutnya rencana perubahan dapat dimulai.

3. Mengkomunikasikan Kebutuhan akan Perubahan, Setelah semua pihak yang berpotensi terkena dampak oleh perubahan dapat teridentifikasi, kemudian kepala sekolah melakukan pertemuan dengan stakeholders untuk mendiskusikan kebutuhan akan perubahan. Beberapa penghakiman akan diperlukan di sini, terutama ketika berhadapan dengan kelompok yang lebih besar. Sebagai seorang manajer, kepala sekolah melakukannya dengan baik dengan mengajak semua stakeholders untuk membahas kebutuhan akan perubahan. Kebutuhan ini harus diidentifikasi dalam bahasa yang jelas dan tidak mengancam. Kepala sekolah menjelaskan alasan mengapa percaya bahwa perubahan kurikulum diperlukan, tapi tetap nonpersonal. Kepala sekolah tidak mengidentifikasi perubahan apa yang akan terjadi, hanya perubahan yang dibutuhkan untuk memungkinkan lebih baik bagi stakeholders guna memenuhi komitmennya. 
4. Pada saat kepala sekolah bertemu dengan stakeholders, dimanfaatkan untuk meminta ide mereka yang mungkin akan terkena dampak. Pada awalnya, kepala sekolah mungkin tidak ingin bertemu dengan semua orang. Sebagai contoh, jika muncul terminasi yang mungkin menjadi bagian penting perubahan, kepala sekolah tidak ingin menyertakan orang yang mungkin diberhentikan. Dalam banyak kasus, kepala sekolah mungkin harus bertemu dengan semua orang, atau perwakilan setiap orang yang akan terkena dampak. Ini adalah penting karena sangat meningkatkan probabilitas bahwa semua keberatan terhadap setiap perubahan yang diusulkan akan menjadi dikenal, dan jika kepala sekolah tahu tentang keberatan mereka, kepala sekolah dapat mengambil langkah-langkah untuk meringankan mereka. Ini adalah area di mana para kepala sekolah sebagai pemimpin unggul mengkomunikasikan kebutuhan untuk perubahan kurikulum, dan mendapatkan pekerja untuk mendukung perubahan.

5. Meminta Komentar, Setelah kebutuhan akan perubahan kurikulum yang akan diberlakukan di sekolah sudah diputuskan, kepala sekolah selalu meminta komentar dari perwakilan guru, orang tua peserta didik atau komite secara kelembagaan. Dengan meminta bantuan untuk mengidentifikasi apa yang bisa menjadi perubahan, dan bagaimana mungkin dilaksanakan secara efektif, pihak pihak yang terdampak tersebut tersebut dibawa ke dalam proses perubahan dan beberapa resistensi/penolakan terhadap perubahan dapat dikurangi. Mengajak orang yang akan terkena dampak perubahan merupakan bagian dari solusi, dan bukannya bagian dari masalah, sehingga dapat membangun rasa kepemilikan dalam pengembangan perubahan. Dengan begitu maka mereka yang akan terkena dampak diharapkan lebih mudah menerima perubahan dan menjadi merasa kurang terancam lagi.

6. Mengembangkan Rencana Untuk Perubahan, langkah berikutnya yang dilakukan kepala sekolah di SD Negeri Pelita Karya Jalancagak Subang Setelah mengidentifikasi kebutuhan untuk perubahan kurikulum dan meminta komentar dari orang-orang di sekitar, selanjutnya merencanakan cara terbaik untuk menerapkan perubahan. Ada banyak hal yang menjadi dipertimbangkan dan diperlukan rencana kompleks yang mendalam. Dalam hal ini, kepala sekolah melakukan pekerjaan rinci ini karena ada banyak persyaratan yang harus dipertimbangkan, seperti anggaran yang dibutuhkan untuk menerapkan perubahan, sumber daya yang perlu dialokasikan untuk perubahan, dan para guru yang akan ditugaskan menjadi garda terdepat dalam implementasi kurikulum sebagai akibat dari perubahan. Kepala sekolah bersaama komite senantiasa meninjau persyaratan untuk perubahan dan menentukan sekaligus menggabungkan tujuan perubahan kurikulum dan tujuan pendidikan pada umumnya.

7. Memantau Perubahan dan Menyesuaikan Sesuai Kebutuhan, langkah terakhir yang dilakukan kepala sekolah, setelah pelaksanaan perubahan kurikulum ini berlangsung, bersama semua pihak yang terlibat dalam implementasi kurikulum memonitor kemajuan rencana tersebut. Jika masalah yang tak terduga berkembang, maka melakukan modifikasi rencana 
Kompetensi guru di SD Negeri Pelita Karya Jalancagak Subang, berdasarkan hasil observasi dan wawancara dapat dikatakan telah mampu mengimplementasikan kurikulum 2013. Beberapa indikator yang dapat dijadikan pengukuran keberhasilan tersebut, diantaranya adalah guru telah mampu menciptakan suasana pembelajaran seperti berikut :

a) Menjadikan peserta didik dari diberitahu menjadi mencari tahu

b) Dari guru sebagai satu-satunya sumber belajar menjadi aneka sumber belajar

c) Dari pendekatan tekstual menjadi pendekatan ilmiah

d) Dari pembelajaran berbasis konten menjadi pembelajaran berbasis kompetensi

e) Dari pembelajaran parsial menjadi terpadu

f) Dari pembelajaran yang menuntut jawaban tunggal menjadi pembelajaran multi dimensi

g) Dari pembelajaran verbalisme menjadi pembelajaran aplikatif

h) Peningkatan kesimbangan antara hardskill dengan softskill

i) Pembelajaran mengutamakan pembudayaan dan pemberdayaan peserta didik untuk menjadi pembelajaran sepanjang hayat

j) Pembelajaran yang menerapkan nilai-nilai keteladanan (Ing Ngarso Sung Tulodo), pembelajaran yang membangun kemauan (Ing Madyo Mangun Karso), dan kreatifitas (Tut Wuri Handayani)

k) Pembelajaran yang berlangsung di rumah, sekolah dan masyarakat

l) Pembelajaran yang menerapkan prinsip siapa saja adalah peserta didik, siapa saja adalah guru, dan dimana saja adalah kelas

m) Menggunakan Teknologi Informasi (TI) untuk efisiensi dan efektifitas pembelajaran; dan

n) Pengakuan atas perbedaan individual dan latar bekang budaya peserta didik

Berdasarkan hasil pengamatan, bahwa guru PAI di SD Negeri Pelita Karya telah mampu mengaplikasikan pengetahuan, keterampilan dan sikap, serta dapat meningkatkan kualitas proses pembelajaran para peserta didik, dengan mempertimbangkan kesesuaian dan ketepatan aktifitas para peserta didik untuk memaksimalkan hasil belajarân. Pengertian ini menyimpan makna substantif yang lebih luas dari sekedar pelaksanaan proses pembelajaran yang hanya mencakup perencanaan, pelaksanaan dan evaluasi proses dan hasil belajar.

Keterampilan guru untuk melakukan pengelolaan kelas bisa memberikan dukungan efektif terhadap pelaksanaan proses pembelajaran, kemampuan memanfaatkan teknologi informasi untuk mendukung proses pembelajaran baik dalam konteks sebagai sarana pembelajaran maupun sebagai sumber belajar. Kemudian, guru PAI juga telah mampu berkomunikasi dengan baik terhadap peserta didik, orang tua atau keluarga para peserta didik, termasuk komunikasi dengan masyarakat, baik sebagai user maupun stakeholder sekolah.

Temuan lainnya selama pbservasi dilaksanakan adalah kemampuan individual guru untuk mengkoordinasikan dan mengkombinasikan antara sumber-sumber yang tampak (seperti materi pelajaran dalam bentuk buku, makalah, kasus-kasus dan teknologi seperti software dan hardware), dengan sumber-sumber yang tidak tampak (seperti pengetahuan, keterampilan dan pengalaman), dalam rangka mencapai efisiensi dan efektifitas dari sebuah proses pendidikan dan pembelajaran. 
Uraian di atas dapat dikatakan bahwa kemampuan guru PAI telah mampu mengkombinasikan dan mengkoordinasikan dua sumber belajar peserta didik, yakni sumber-sumber yang tampak dan terukur dengan sumber-sumber tidak tampak yang dimiliki guru. Upaya-upaya koordinasi dan kombinasi tersebut menuntut skill dan keahlian guru, baik manajerial, komunikasi, pengembangan konten bahan ajar melalui penelitian, dan berbagai keahlian lain yang mendukung peningkatan hasil belajar peserta didik.

\section{Kesimpulan}

Kurikulum 2013 Pendidikan Agama Islam di kelas VI SD Negeri Pelita Karya Jalancagak Subang sudah diimplementasikan dengan baik. Dari hasil observasi, wawancara dan studi dokumentasi yang dilakukan peneliti menunjukkan kesesuaian dan kesejalanan informasi yang diterima dari berbagai sumber. Hasil wawancara dengan kepala sekolah, komite sekolah, dan guru wali kelas VI serta guru PAI di kedua sekolah diperoleh informasi bahwa kurikulum 2013 pada Pendidikan Agama Islam dapat dilaksanakan dengan sangat baik. Data ini didukung dengan dokumentasi dokumentasi yang berkaitan dengan implementasi tersebut.

Karakter peserta didik kelas VI SD Negeri Pelita Karya Jalancagak Subang, berdasarkan hasil pengamatan langsung terhadap peserta didik menunjukkan karakter yang baik sampai dengan sangat baik. Hasil amatan ini didukung dengan hasil wawancara dengan kepala sekolah, komite sekolah, wali kelas VI dan guru PAI di kedua sekolah. Begitu juga berdasarkan data pada dokumen penilaian peserta didik yang ada pada wali kelas dan guru PAI, pada umumnya peserta didik menunjukkan karakteristik yang baik sampai dengan sangat baik sesuai dengan indikator karakter yang ditetapkan.

Implementasi kurikulum 2013 Pendidikan Agama Islam dapat membentuk karakter peserta didik kelas VI SD Negeri Pelita Karya Jalancagak Subang. Kurikulum 2013 pada pelajaran PAI di kedua sekolah dapat menjadi fasilitas dan pendukung terjadinya perubahan karakter peserta didik. Hal ini dapat dilihat dari antusiasme peserta didik melakukan perubahan perubahan perilaku selama pembelajaran dengan kurikulum 2013. Data ini didukung oleh berbagai informasi dari para informan, bahwa setelah diberlakukan kurikulum 2013, perubahan perilaku peserta didik menunjukkan perubahan yang signifikan.

Faktor faktor pendukung utama terlaksananya kurikulum 2013 dengan baik, adalah keinginan yang kuat dari semua pihak yang terkait dengan pengelolaan sekolah untuk memajukan sekolahnya masing masing, terutama di dalam pembinaan karakter peserta didik. Daya dukung paling besar adalah dari para guru PAI sebagai pelaksana utama pembentukan karakter peserta didik itu sendiri. Para guru sangat antusias untuk mengaktualisasikan materi pelajaran yang ada di dalam kehidupan peserta didik. Faktor pendukung lannya adalah respon dan peran serta yang positif dari kepala sekolah, komite sekolah dan masyarakat sekitar yang senantiasa berpartisipasi secara aktif di dalam implementasi kurikulum di kegiatan sekolah. Faktor faktor pendukung yang ada di SD Negeri Pelita Karya Jalancagak Subang dalam implementasi kurikulum 2013 PAI dalam pembentukan karakter peserta didik, pada dasarnya sama di kedua sekolah. Hal ini kemungkinan karena kedua sekolah lokasinya relatif berdekatan sehingga kultur masyarakatnya relatif sama.

Beberapa aspek yang dapat dikatagorikan penghambat dalam implementasi kurikulum 2013 PAI di kedua sekolah adalah ketersediaan waktu dan sarana pembelajaran yang sangat terbatas. Walaupun ada fakor faktor penghambat di SD Negeri Pelita Karya dalam implementasi kurikulum 2013 PAI dalam pembentukan karakter peserta didik, namun secara kuantitatif maupun kualitatif tidak begitu berpengaruh. 
Bibliografi.

Andriani, Dian. (2017). Implementasi Kurikulum 2013 Pada Mata Pelajaran Al-Qur'an Hadits Di Mtsn Pucanglaban Tulungagung.

Ayda, Apriliani. (2020). Implementasi Kurikulum 2013 Dalam Meningkatkan Hasil Belajar Pendidikan Agama Islam Di Smp Eka Sakti Banyumanik Semarang. Semarang: Universitas Wahid Hasyim.

Djaelani, Moh Solikodin. (2013). Peran pendidikan agama Islam dalam keluarga dan masyarakat. Jurnal Ilmiah WIDYA, 1(2), 100-105.

Hisyam, Muhamad, \& Pamungkas, Cahyo. (2016). Indonesia, Globalisasi, dan Global Village. Yogyakarta: Yayasan Pustaka Obor Indonesia.

Huda, Muh Nurul. (2014). Perubahan Parsial di Lembaga Pendidikan Islam. Ta'allum: Jurnal Pendidikan Islam, 2(2), 131-145.

Indrawan, Irjus. (2015). Pengantar manajemen sarana dan prasarana sekolah. Yogyakarta: Deepublish.

Mataputun, Yulius. (2018). Kepemimpinan Kepala Sekolah: Berbasis Kecerdasan Intelektual, Emosional, dan Spiritual Terhadap Iklim Sekolah. Yogyakarta: Uwais Inspirasi Indonesia.

Mubarrok, M. Husni. (2019). Upaya guru ilmu pengetahuan sosial dalam mengatasi kesulitan belajar siswa pada kelas VIII di MTs Negeri 4 Pasuruan. Jawa Timur: Universitas Islam Negeri Maulana Malik Ibrahim.

Noor, Amirudin. (2019). Problematika pembelajaran pendidikan agama Islam di era digital. Prosiding Seminar Nasional Prodi PAI UMP. Jakarta.

Nurdyansyah, Nurdyansyah, \& Fahyuni, Eni Fariyatul. (2016). Inovasi model pembelajaran sesuai kurikulum 2013. Jawa Timur: Nizamia Learning Center.

Suradi, Ahmad. (2018). Pendidikan Berbasis Multikultural dalam Pelestarian Kebudayaan Lokal Nusantara di Era Globalisasi. Wahana Akademika: Jurnal Studi Islam Dan Sosial, 5(1), 111-130.

Susanto, Moh Rusnoto, \& Retnaningsih, Rahayu. (2018). Melacak pemikiran avant garde Ki Hadjar Dewantara melalui konsep pendidikan nasional sebagai fenomena quantum leap dalam perspektif filsafat organisme. Prosiding Seminar Nasional, 1(1). Jakarta.

Wahono, Margi. (2018). Pendidikan Karakter: Suatu Kebutuhan Bagi Mahasiswa di Era Milenial. Integralistik, 29(2), 145-151.

Yusmina, Erra, \& Murniati, A. R. (2014). Implementasi Manajemen Mutu Terpadu dalam Peningkatan Kinerja Sekolah Pada SMK Negeri 1 Banda Aceh. Jurnal Administrasi Pendidikan: Program Pascasarjana Unsyiah, 2(2).

Yusuf, Irwan, \& Asrifan, Andi. (2020). Peningkatan Aktivitas Kolaborasi Pembelajaran Fisika Melalui Pendekatan Stem Dengan Purwarupa Pada Siswa Kelas Xi Ipa Sman 5 Yogyakarta:(Improving Collaboration of Physics Learning Activities through the STEM Approach). Uniqbu Journal of Exact Sciences, 1(3), 32-48.

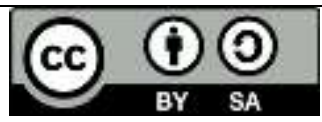

This work is licensed under a Creative Commons Attribution-ShareAlike 4.0 International License. 